\title{
Slovenes, the Balkans, and the Yugoslav Idea, or A Short Story about a Lengthy Cow
}

\author{
BOŽIDAR JEZERNIK \\ Dept Ethnology and Cultural Anthropology, \\ Faculty of Arts, University of Ljubljana
}

\begin{abstract}
In one of her articles, Dunja Rihtman-Auguštin (2000: 211-36) discusses the choice of words in contemporary Croatian political parlance by which politicians at the end of the twentieth century mobilised their constituency by expressing their attitudes towards what was good and acceptable for Us, and what was bad and thus unacceptable for Our ways. In her enlightening article, full of witty insights, she argues that the notion "Balkan" belongs equally to history and to imagination. Although the Balkans are always east of Us, she suggests, the Balkan mentality is here, with Us, not somewhere else. Rihtman-Auguštin's article inspired me to analyse the history and image of the term Balkan in Slovene in the second half of the nineteenth and early twentieth centuries, that is to say, in the period when Slovene national consciousness developed.
\end{abstract}

Key words: Modernity, Ottoman Empire, Slovene nationalism, The Balkans, Yugoslavia

\section{THE PENINSULA WITHOUT A NAME}

Although geographically close, Slovenes knew but little about the Balkans and their language even lacked a name for the peninsula. In Slovene, in the 1850 s and 1860s, the region lying south-east of Slovene lands was referred to simply as europejska Turčija (European Turkey), in distinction to azijatska Turčija (Asiatic Turkey) (see, e.g., Anon. 1852: 143; 1853b: 378; 1854: 16; Podgoriški 1862: 327; Anon. 1868: 92). The term balkanski polotok, ("the balkan peninsula", uncapitalised as in the original), was introduced only in the late 1860s (Anon. 1878b: 2; Potočnik 1878: 1). ${ }^{1}$ Arguably, the choice was

\footnotetext{
${ }^{1}$ Until the beginning of the nineteenth century the Balkan Peninsula had no name. Only in 1808 did the German geographer August Zeune give it the name Hämushalbinsel, which he subsequently changed to the Balkan Peninsula, following the usual practice of naming a region after a prominent mountain range.
} 
at least partly due to the fact that in the first half of the nineteenth century the Stara Planina mountain range became familiar as the primary theatre of the Russo-Turkish wars (Anon. 1853a: 366; Slovenski oficir 1878: 1; see also Jezernik 2004: 24). However, the Balkans, as the popular saying has it, remained "behind the nine Turkish mountains". Slovenes knew very little about the land and its people and, even more curiously, were unable to tell the difference between Serbian and Turkish flags:

It was a pleasure for me to see for the first time on the Sava a Serbian ship with a tricoloured flag, and I inquired of a peasant whether it was a Serbian or a Turkish flag, for all the people were wearing fezzes and Turkish trousers (čakšire). They replied to me that it was Serbian, which made my heart thrill, for I saw for the first time a ship under a Slavic flag. This is very dear to a Slav. (Anon. 1866: 96)

The Balkans started to play a role on the geopolitical map of Slovenes only after 1870, when the Prussian army triumphantly entered Paris. The Prussian victory in the war with the French was something that no one had dared to predict. When it happened, the map of Europe changed for good.

According to the historian Vasilij Melik (1997: 17-8), in the 1870s and 1880s Slovene intellectuals interpreted political events from the viewpoint of conflict and competition between three great groups of people: the Romance, Germanic, and Slavic groups. The liberal newspaper Slovenski Narod thus interpreted the Franco-Prussian war in 1870 as a victory of the Germans over the Romance peoples, who were "downtrodden and harmless", and predicted a future clash between the Germans and the Slavs, which would be a different kind of confrontation: "The Slav will have to fight not for domination, but for his freedom, to save himself from such 'civilised' people" (Anon. 1870b: 1). The fall of Paris in the Franco-Prussian War reverberated throughout the continent, giving German nationalism in Austria a strong impetus. Nationalistic celebrations of Prussian victories, however, triggered a reaction, making Slavs in Austria realise that "nemškutarstvo (a pro-German orientation, B. J.) leads to Prussianism, and requires national death for the Slovenes" (Anon. 1870a: 2-3).

In view of this, Slovene nationalists turned their eyes towards the east and south-east of the continent, especially in 1875 and after, when Balkan Slav insurgencies began. Slovene nationalists were confident that the liberation of the Slavs of the Ottoman Empire would prove helpful in their political struggle to establish Zedinjena Slovenija (United Slovenia). Thus, the

Zeune's choice was rather arbitrary, however, as the Balkan Mountains, formerly called the Haemus (from haima, the blood of Typhon), in what is now Bulgaria and known as Stara Planina (Old Mountain), constitute neither the most extensive nor the highest mountain system in the peninsula (Jezernik 2004: 23). 
conservative weekly Novice gospodarske, obrtniške in narodne suggested that in the wake of these events "the future of eighty million Slavs in Europe had been placed on the agenda" (- č - 1877: 45).

Soon, this viewpoint became so strong that it routinely dictated the nature and type of descriptions, even the manner of observing and reasoning (cf e.g. Nikočević 2008: 189). When on 21 April 1877 the Russian tsar declared war on the Ottoman Empire, Slovene newspapers drummed up enthusiasm among their readers by referring to Slavdom in order to embolden them to support their cause. On 1 May 1877, the Sokols ${ }^{2}$ of Ljubljana organised a meeting on Šmarna Gora near Ljubljana. On this occasion the writer and politician Josip Jurčič proposed a toast "to the happy victory of brotherly Slavic Russian forces on the banks of the Danube and the Black Sea". His toast was followed by passionate singing of the Russian anthem (Izv. Dop. 1877: 3).

The European balance of power, however, dashed the hopes of Slovene nationalists, and statements that the victories of Russian armies would bring about instant results also for the Austrian Slavs gradually vanished from Slovene newspapers. Instead, new ideas emerged with regard to the possible closer trade connections between Slovenes and the newly established Balkan states. Thus, Slovenski Narod wrote that the liberation of the Slavs from the "Turkish" yoke would eventually open trade routes towards the Balkans. According to the newspaper, the insurgencies of Balkan Christians and the Russo-Turkish war of 1877 would bring freedom to the Slavic rayah, and the trade in liberated lands would increase and with it the need for knowledge of Yugoslav dialects. It suggested that the trade routes would open wide for the Austrian Yugoslavs in particular, and they would become the go-betweens in trade between the Balkans, the Orient, and other European countries (Izv. dop. 1878: 2). The conservative daily Slovenec, too, had no doubt that after the acquisition of south-eastern European lands trade would advance, and that it would come into the hands of Slavs who had already established trading ties with Bosnian "Turks" and knew their language (Anon. 1878a: 1).

\section{DRANG NACH BALKAN}

In the wake of the Russo-Turkish War, the Berlin Congress convened in 1878, purportedly to create a lasting peace in the Balkans, to meet the needs of the Balkan people, to pacify the whole of Europe, and to eliminate any occasion for dissatisfaction on all sides. However, instead of peace and the salvation

\footnotetext{
${ }^{2}$ Sokol was a gymnastics organisation first founded in Prague in 1862 by Miroslav Tyrš and Jindřich Fügner. The founding fathers of the organisation, which eventually spread across all the Slavic territories, viewed it as physical, moral, and intellectual training for the (Slavic) nation.
} 
of the Balkan nations, which were its proclaimed aims, the Berlin Congress brought about the disappointment of the Bulgarians, conflict between Greece and the Ottoman Empire, Austro-Hungarian warfare against Muslims in Bosnia-Herzegovina, and feelings of deprivation in Serbia. To cut a long story short, discontent reigned supreme.

The Berlin Congress concluded with an agreement aimed at "rectifying the European geographical map, which was so pitilessly reshaped by the heir of the revolution - Napoleon". Article 25 of the Berlin Agreement gave Austria-Hungary the mandate to occupy provinces between Dalmatia, the Drina, and Croatia with the aim of restoring peace and order. Hence, the Dual Monarchy capitalised on "Turkish evil deeds against the Christian rayah" and inaugurated its political action, which some Slovene nationalists called a “German Drang nach Balkan!" (Anon. 1908b: 1).

At the time of the Austro-Hungarian occupation of Bosnia-Herzegovina, for Slovenes anti-Turkish sentiment was combined with Slavic sentiment and with religious, Christian consciousness. Talking politics meant talking about oppressed Christians, about their suffering under "the Turkish yoke", about the "savage Turks", "Turkish beasts", "Turkish bloodthirstiness", and so on. During the occupation of Bosnia-Herzegovina in 1878, anti-Turkish sentiment increased as a consequence of the fights between the occupation troops and the insurgents. At that time, to Slovenes the term "Turk" meant Muslims from Bosnia-Herzegovina. Letters written by Slovene soldiers from Bosnia-Herzegovina described them as beasts that should be exterminated. Or, in the words of a Slovene corporal in a letter to his family from 22 August 1878:

The Turks torture captured and wounded soldiers terribly; they bind them, cut off their noses, ears. They are not human, they are beasts, and we should completely exterminate them. We have killed and captured a lot of them. Their stature and their eyes are the duplicate of those of Jews in old images torturing Christ. (Anon. 1878c: 1)

It came as a "real shock" to Slovene soldiers in the Austro-Hungarian occupying army when they discovered that "the Turks" were not Turks at all, but Slavs speaking a similar language (Melik 1997: 17). The fact, that the Muslims of Bosnia-Herzegovina were Slavs was news to many Slovenes even in 1907 (Kveder-Jelovšek 1907: 1).

Russian victory in the war with the Ottoman Empire stirred, yet again, great expectations. Slovene nationalists were looking to Russians "who hastened to help their Slavic brothers in the Balkans" and to set free the Balkan Slavs. They felt that Russian victories in the Balkans would give a boost to their national ambitions, too. For that reason, Slavic deputies in the 
state assembly advocated the idea that the Austro-Hungarian army should immediately march into Bosnia-Herzegovina (Vošnjak 1912: 56).

However, when the Habsburg Empire occupied Bosnia-Herzegovina, in 1878, the then Foreign Minister of the Empire, Count Gyula Andrássy, exclaimed that "a solid wedge has been knocked into Yugoslav flesh". Henceforth, Slovene nationalists looked at Bosnia-Herzegovina after the occupation with more scepticism, and, in 1908, they interpreted the annexation as a clear sign of Austro-Hungarian imperialism striving to subjugate the whole Slavic Balkans down to Thessaloniki in order to exploit the "rich Balkan lands" and "put Slavic riches into German pockets" (Anon. 1908a: 1).

Ever more voices could be heard claiming the Balkans for the Yugoslavs. The rationale given was that the Slavs had lost their kingdoms, and with them the respect of the world, after the fall of Constantinople, when "Mohammed clashed with Christ in an iron grip" and changed the Balkans into a huge jail crammed with slaves. However, as Slavic patriots pictured it, this "sorrowful period" of Slavic history should not last forever, and called people's attention to the fact that "Kraljević Marko ${ }^{3}$ was not dead, that his steed was not dead either, and that his spear had not rusted", but that he was just sleeping somewhere in a cave waiting for the fairy Slovinkinja to wake him up, to win freedom for his race (Anon. 1908c: II).

\section{THE BALKAN WARS}

The notorious "powder keg of Europe" exploded yet again in 1912, when the first Balkan War broke out and Balkan Christian states declared war on the Ottoman Empire. Then, Slovenes watched with deep interest "the Balkans and its bloody battlefields", its geography and history, as advertised in Slovenec on 3 November 1913. As "the Turk" was - in the eyes of Slovenes - the "hereditary enemy" (Simonič 2010: 69-70), they saw the first Balkan War as a truly holy war of the Cross against the Crescent, which should have brought freedom for the oppressed Slavic peoples of the Ottoman Empire (Dolenec 1921: 370).

Watching closely the progress of the Slavic Kingdoms (Bulgaria, Serbia, and Montenegro) on the battlefields, they imagined that Southern Slavs would be ever more closely linked together. They supposed that such a course of events would be beneficial in particular to Slovenes, for they were "the most exposed to the pressure of our northern neighbours", and their Southern Slavic "brethren" would give them strong backing in their strug-

\footnotetext{
3 "Prince Marko", a mythical figure of Southern Slavs.
} 
gle for their (Slovene) national rights (Vošnjak 1912: 59). Ivan Cankar, the "greatest Slovene writer", articulated this feeling in his public lecture in Ljubljana on 12 April 1913:

When the first shot was fired in the Balkans, its echo resounded in our remotest village. People who were uninterested in politics during their entire lifetime watched this grand drama with a sympathetic heart, not just with interest. And in all of us something awakened which was very much akin to the yearning of a prisoner. However, something else has awakened in us, ever more important and precious - the spark of the power, self-assurance, and vital force which was in full swing in the south, has fallen on Slovene soil, too. The weakling saw that his brother was strong and he began to trust in himself and his future. (Cankar 1959: 393)

Early in 1913, Slovenes still looked to Austria for their future; "not an Austria with previous wrongs", but an Austria whose Balkan politics would not be Slavophobic (Anon. 1913: II). In his speech - received with shouts of applause - on the impact of the Balkan Wars on the Slovene economic and political situation at a meeting organised by the Slovene political association in Trieste, Edinost (Unity), on 12 January 1913, a member of the Austrian parliament, Dr Otokar Rybář, called on Austria-Hungary "to win the Balkans". According to him, this should have been done in such a way that would win "the hearts of the Balkan peoples, thereupon they will reciprocate our friendship and our sympathies". In order to achieve this, Austria-Hungary should wholeheartedly support the struggle of the Balkan Slavs, and by no means fall upon them from behind when they were still on the battlefields. This would only deepen their hatred towards the Dual Monarchy and would be of no use for it, "for we cannot do business with maltreated nations, as we can only conclude good trade contracts with wealthy countries" (Rybár 1913: IV).

Viewpoints on the Balkans and its future, however, were divided in Austria-Hungary. If Slavs watched the region with aspirations for (their) emancipation, the official politics led by German and Hungarian politicians saw in the region, above all else, alluring opportunities to appease their imperialistic ambitions. When the Viennese pro-government press argued that the Balkan nations were then "members of the Western European national community" and Austria-Hungary the only European power that was a Balkan state, suggesting that this gave it the natural right to participate in the "free development of the Balkan nations", the Slovene press in Ljubljana and Trieste raised objections. For Slovene nationalists it would be acceptable that in the Balkans the monarchy should win the influence "which is indispensable for our economic development and which would be a natural 
consequence of the fact that we are linked by consanguinity with brothers here and on the other side of the Sava". But they were wary on account of the imperial politics of divide et impera practised by Austrian diplomacy in the past. What is more, they blamed the Empire for conducting itself as a master in the Balkans, for provoking economic conflicts with Serbia, for being a friend of Turkey until the last moment and for intervening in the Balkan Alliance with the Albanian Question (Anon. 1913: 1).

Along these lines, the Balkan Wars in 1912-13, and the polemics that followed, rallied Slovene public opinion in favour of "the idea of a SerboCroat-Slovene nation" (Vošnjak 1916: 27). Although the regime tried brutally to suppress pro-Yugoslav political sympathies and even imprisoned Ivan Cankar for his alleged pro-Serbian sympathies, police repression proved ineffective in the battle for the hearts and minds of Slovenes. "To a nation like the Slovenes", a member of the Yugoslav Committee in London, Bogumil Vošnjak, explained, "placed between the alternatives of national life and death, the Southern Slav Idea could not fail to bring deliverance from the terrible dread of extinction; it was a choice between being and non-being" (Vošnjak 1916: 27).

\section{THE BRIDGE BETWEEN EUROPE AND THE ORIENT}

The main political results of the Balkan Wars were seen "in the transformation of the map of the Near East and in the transference of the border line between European and Asiatic civilizations from the Balkan Peninsula to Asia Minor" (A Diplomatist 1915: 359). However, this makeover of the geopolitics of Europe failed to bring stability to the south-east of the continent. On the contrary, it soon provoked the Great War. The great bloodbath ended in major changes to the geopolitical map of Europe, one of the most visible changes being the collapse of the Dual Monarchy. After the disintegration of Austria-Hungary, most Slovene territory was incorporated into a new nation-state, the Kingdom of Serbs, Croats and Slovenes, which united the majority of the Southern Slavs. In a country shared with their Slav compatriots, Slovenes no longer referred to the former empire as their homeland, but as the "prison-house of nations" (Jezernik 2006: 101).

A new nation-state of Southern Slavs emerged in the wake of the First World War and Slovene politicians publicly advocated a new standpoint: "The Balkans for the Balkan peoples!" Now, they claimed that the border between the Balkans and the West was the border between Italy and Yugoslavia (Anon. 1919a: 2; Seidl 1919: 2). Within this context, the image of the Balkanite changed, and the Balkans and its people looked like Us. The leader 
of the Slovene People's Party, Dr Anton Korošec, presented the new Balkanite at a great pro-Yugoslav manifestation in Ljubljana on 26 March 1918:

Before the war, men were walking around with revolvers under the belt. But if we come to the Balkans today, we see that they have pipes in place of revolvers and that they bear no arms. (Anon. 1918a: 2)

Soon, they became proud that they made "a bridge from Europe to the Orient", and that the Slovene "healthy, young, dynamic nation" had "all the spiritual and material prerequisites for great cultural and economic accomplishments" (Res 1919: II). They were firmly convinced that the new nation-state would live long. Early in 1919, Slovenec reported on an article, The Future of Yugoslavia, written by "a German from Bosnia" and published by a newspaper "of ill repute", Die Reichspost. The author argued that if the republican principles were to prevail, Yugoslavia would become a loose federation. In this case, the western part - due to its entire past - would be in everlasting opposition to its eastern part. But, if the monarchy were to persist in Belgrade, then it was possible that the Slovene part and Croatia would declare independence and it was quite possible that "when they wake up from chauvinistic-nationalistic dreams into reality, they will look again to establish ties with the West and German culture". Slovenec commented in a few words: "Švab, ${ }^{4}$ you are horribly mistaken!" (Anon. 1919c: 5).

The new Southern Slavic nation state strove to introduce a modern western political life. As the phrase of the day had it, they "no longer wanted to be the Balkans and Austria, but Europe" (Anon. 1919b: 2). In striving to achieve this noble goal, a special role was ascribed to the "Slovene part of the Yugoslav nation" (Res 1919: II). For centuries, Slovenes had lived under the sway of German culture and language. As ascertained by Dr Alojzij Res, they received directly or indirectly from German hands not only their knowledge and familiarity with world cultural and political history, literature, economy, and trade, but they also watched their own history "through German-tinted spectacles". Thus, Res suggested, they gained a lot. Although under German reins, Slovene horizons widened, and with knowledge of the German language they had access to all the spiritual riches of the world. With the German language they also learned a "sense of order and organisation", for which they were renowned as the part of the Yugoslav nation with "the greatest organisational ability" (Res 1919: II). Political freedom, though achieved with the establishment of Yugoslavia, brought about new tasks for the future:

${ }^{4}$ Švab (Swabian) $=$ pejoratively for a German. 
Yugoslavia is, due to its geographical position, to its ethnographic components, due to its political, religious, and cultural history - a bridge between the East and the West. Eastern and Western culture meet on the Yugoslav territory, Eastern and Western Christianity. Therefore, our new cultural orientation has to have a certain leading idea that pervades us and stirs all our cultural activity and leads it in a common direction to a common goal. This leading idea, this common goal, is mediation between Eastern and Western culture, an agreement and a new union between the East and West. (Res 1919: II)

\section{THE NAME GAME}

However, there were some urgent questions that needed to be addressed first. To begin with, what would the name of the new nation be? Should they be Jugosloveni (Yugoslavs, in Serbian) or Jugoslovani (Yugoslavs, in Slovene)? Then, what was the status of the Bulgarians: "Are Bulgarians Jugosloveni or Jugoslovani? Are they human at all?" (M. M. R. 1920: 1). Unification also opened the question of a common literary language, and the Slovene press devoted many pages to this topic. Some argued that Slovenes should adopt the SerboCroatian language, claiming that "if the unification is not accomplished now, if we continue to cling to our dialect in literature - we will never unite" (U. F. 1920: 1). Nevertheless, many maintained that this could estrange Slovene minorities in Austria and Italy.

Officially, the Vidovdan Constitution ${ }^{5}$ resolved the questions by proclaiming Slovenes, Croats, and Serbs (others were not named) as three different "tribes" of "one nation". In line with the opinion that a nation consists of people related by blood who speak the same language (see, e.g., Pripravljalni odbor 1913: 127), the Constitution proclaimed Serbo-Croatian-Slovene as the official language of the new nation-state, and its citizens to be of SerboCroat-Slovene nationality. These constitutional provisions were based on Vatroslav Jagić's assessment that Southern Slavs spoke but different dialects of a single language (Jagić 1895). ${ }^{6}$

The Vidovdan Constitution, however, soon proved not to be a solid foundation stone, but a colossal stumbling block. Namely, political opposition argued that the new Constitution introduced Serbian hegemony and that the Greater Serbian spirit ruled the new nation state (Anon. 1924: 1). In 1918, the National Council of Slovenes, Croats and Serbs, in its proclamation "For full

\footnotetext{
${ }^{5}$ The Vidovdan Constitution was adopted on St Vitus Day, on 28 June 1921.

6 "Indeed, a wonderfully beautiful rainbow spans in a magnificent arch over the Balkans, on their shoulders two mighty heroes are carrying it: on one side Trieste, with Constantinople on the other" (Županić 1907: 616-17).
} 
liberty and unification" signed by Anton Korošec, Ante Pavelić, and Svetozar Pribičević and published in Slovenec in the Slovene language, used the SerboCroatian term ujedinjenje for unification (Korošeć, Pavelić and Pribičević 1918: 1). During the 1920s, Slovenec abolished the term and replaced it with Slovene term zedinjenje, and even claimed that ujedinjenje was "a mistake" (Anon. 1920: 1), while Slovenski Narod continued using ujedinjenje or uedinjenje. After the assassination of King Alexander I, on 9 October 1934, a ruler who had transformed the Kingdom of Serbs, Croats and Slovenes into the Kingdom of Yugoslavia, thus earning the title Ujedinitelj (the Unifier), there appeared in Slovenec an article in which its author discussed the question "Ali smo se zedinili? Ujedinili? Uedinili?" (Did we unite?) The author argued that, in Slovene, only the term zediniti (to unite) was acceptable, since ujediniti was a Serbo-Croat word and uediniti supposedly meant "to disunite" (Aristides 1934: 4).

In France, in the process of creating the nation state, they turned - in a famous phrase of Eugene Weber's - "peasants into Frenchmen"; by contrast, in the nation state of Southern Slavs the respective (national) elites continued to regard the peasants as Slovenes, Serbs, and Croats. When Italy was unified in 1866 less than $2.5 \%$ of the population used Italian as their first language, the vast majority employing a wide range of dialects. This accounts for Massimo d'Azeglio's call at the time of Unification: "Ora che l'Italia è fatta, bisogna pensare a fare gl'Italiani!" (We have made Italy, now we have to make Italians!) (Ušeničnik 1914: 296; Hobsbawm, 1975: 89).

When the first Southern Slav nation-state was established, nobody spoke Serbo-Croatian-Slovene, and the leading political parties had not striven to make Yugoslavs, but Serbs, Croats, and Slovenes. Separated by state borders between the Habsburg and Ottoman Empires and, after 1878, between Austro-Hungary, and Serbia and Montenegro, they did not know much about each other. In the western part there was an image of Serbs based on aggressive anti-propaganda, which represented the inhabitants of both Serbian Kingdoms as "barbaric people" who, with Byzantine culture, also received its worst elements (Ušeničnik 1914: 307). On the other hand, the Serbian people did not know much about Southern Slavs from Austria-Hungary and used to mistake them for "Germans" and "Hungarians". In a word, they looked upon them as "hostile Švabs" (Leskovec 1918: 1).

In the Slovene part of the new nation state, two political parties with great support from the voters, the conservative Slovene People's Party and the Communist Party, abstained from voting on the Constitution. Catholic politicians were afraid that Orthodoxy would prevail, and Communists were opposed to the monarchy and capitalistic social order. Only political representatives of the Slovene bourgeoisie voted for the Constitution. The Slovene bourgeoisie saw Yugoslavism as a "door to a land of economic prosperity" 
(Vošnjak 1919: 1). Their earlier wish to become the intermediary in trade between the East and West had not turned out the way they wanted, and in the end they saw with their own eyes that the supposed present did not come gift-wrapped.

After 1921, ever more dissenting voices could be heard in the western part of the new nation state, claiming "We are not brethren!" and "Serbianness, Croatianess, and Sloveneness are endangered!" (Anon. 1919b: 2-3). Those who pointed out that the citizens of the new nation state needed to be aware that they were one nation and that they had to break with traditions and begin to set up new political formations were losing their supporters. This meant that Slovenes tried to prove that their country did not belong to the Balkans, but that they were, indeed, Central Europeans (see e.g. Berend 2003: xiii). Consequently, Slovene and Croat members of the National Assembly began to strive for closer ties with Germany, in order to establish "German-Slavic solidarity, which would bring a new age to Europe" (Anon. 1927b: 1).

The response to these tendencies was a process involving the deGermanisation of the Slovene past (Jezernik 2010: 36) in which the German language in Slovene schools gave way to French. A visible sign of this process was the unveiling of the monument to Napoleon in Ljubljana, on 13 October 1929. According to the new interpretation of the past, in the early nineteenth century the French were not occupiers, but instead "brought to us a new life, laid the foundations for the new era of our national development" (Rus 1929: 7). However, beneath the surface of the celebratory eulogising at the official opening of the monument it was possible to detect polemics stemming from diverse views of the past and present. While General Stevan Hadžič, Minister of Defence, speaking on behalf of the royal government, emphasised the "patriotic awareness of our common homeland, of the deep national and state-forming consciousness" (Hadžić 1929: 1), Slovenec commented that

Croats will continue to be Croats, Serbs Serbs, and Slovenes Slovenes. Yet all will be proud to be Yugoslavs. (Anon. 1929: 1)

In short, the differences in the perceptions of the "three brotherly tribes of one nation" were slipping apart, and, in Slovene (and Croat), the terms "the Balkans, Balkanism" was slowly but surely acquiring the negative connotation conveyed by the Old Greek word barbar (Anon. 1927a: 1). In Slovene, Balkan (the Balkans) developed into the epitome of the European periphery and a synonym for a lack of civilisation and backwardness. Whenever the term was used, it conveyed negative connotations of backwardness, passivity, filth, disregard for women, conspiracy, unscrupulousness, opportunism, indolence, superstition, and so on. 


\section{PROGRESS VERSUS BACKWARDNESS}

We have followed how Slovenes had grand expectations and plans, after 1875 , in connection with the Balkans. Paradoxically, however, their interest in the south-eastern neighbourhood was but shallow, and up until the Great War, for the great majority of Slovenes, "the dark Balkans" commenced immediately south of Novo Mesto (Ilešič 1913: 126). When, in the first decade of the twentieth century, the anthropologist Niko Zupanič, the author of Ave Illyria!, who later proudly called himself "the Father of the Modern Yugoslav Idea" (Zupanič 1916: 56), published several studies on the Balkans, his works were deemed "a curiosum, the labour of an idealist-eccentric, who "my Carniolan makes fun of'" (Ilešič 1913: 126). The star of the "dreamy Illyrian" flared up - for a short while - after the end of the Great War when Slovenes ascertained that "nowadays we are all more or less Illyrians". However, in the first issue of Etnolog, the first Slovene periodical for anthropology and/ or ethnology, the reviewer France Kotnik mentioned Zupanič's article on the physical anthropology of the Ottoman Turks in a few words, claiming that "This treatise will surely find but few readers" (Kotnik 1927/28: 342).

In the second half of the nineteenth century the economic development of the Balkans was already lagging behind Central Europe and the busy scenes of industry and "progress", so characteristic of western and central European cities, were still unknown in the south-eastern part of the continent. While on the Austrian side of the border travellers could observe "forms and the outward appearance of an advanced civilization", they were seeing nothing but "misery and degradation" on the other side of the border (Skene 1853: II, 98).

There are Slavs still free of foreign corruption, as they once were, for over 300 years they remained almost on one and the same level. Although not civilised, the people are not corrupted, they are robust and they still have not picked up the European effeminacy that deprived Western Europe of almost all its strength. One grand thought, one inflammable sparkle, one powerful man and the putrid pillars of European Turkey would tremble and collapse. (Anon. 1852: 143)

In their minds, freedom and progress, development and economic growth went together, hand in hand (Berend 2003: 1-2). Thus, when they were turning their eyes towards the Balkans they did not notice just high-spirited Slavic people struggling for national freedom and equality; the more knowledgeable also became aware of the economic potential of the region:

The situation in the south, where our brothers live, will soon change, liberated peoples will be their own masters and they will advance in the Slavic 
spirit. Literature will advance, songs will be sung about glorious battles for freedom that ended favourably. The soil in the Balkan Peninsula will be looked at more accurately, trade and business will be set up when communications are built between towns and villages. Deserted and neglected land will be brought under cultivation, possibly hidden ore will be unearthed - in all, a completely new world will be created there. And shouldn't we be looking forward to that? (Slovenski oficir 1878: 2)

It follows that the image of the Balkan Slavs was constructed with the idea of a "cultural anachronism" (Chakrabarty 1992). This notion was a powerful element in the cultural construction of what Slovenes called "Europe" in contradistinction to "Asia" or, subsequently, "the Balkans". From this point of view, "Asia" and/or "the Balkans" served to them as a kind of mirror in which they could look at themselves and notice how "modern" and "progressive" they were (cf. Jezernik 2004: 29). Thus, since its introduction into the Slovene language, the term Balkan has been used not only as a geographic name, but it has also connoted the lack of a nation state and the lack of industrialisation, on the one hand, and the absence of a modern, urbanised society, on the other. As a consequence, a geographical name has not been merely a symbol of a certain geographical region, on the contrary it has also served as a tool of differentiation between Us and Them, including Us into "Europe" and "the present" (Nadel-Klein 1996: 110), on the one hand, and excluding Them from it, on the other.

This point of view was the basis of the feeling of contempt towards their more southern "brethren", who were supposedly less civilised. The printed media time and again reported on the backwardness, corruption, and moral decay of the neighbouring Slavs and on the "Asiatic circumstances down there". And, inversely, they exalted those who spoke their dialect themselves, along with their honesty, and this frequently in such a connection that any Slav who did not call himself a Slovene (or a Croat, or a Serb, etc.) seemed $a$ priori like a dishonest person:

A Styrian teacher expresses himself contemptuously about Carniolan schools. A Carniolan speaks scornfully about "bogmeji on the Ottoman borders", a Croat looks down upon a Serb - "a cowherd" and so we in turns nicely despise each other. In such a way, as Vodnik said: "Every village has its own voice, however each pokes fun at the other village." (Ilešič 1910: 18)

Thus, according to Ilešič, Southern Slavs adopted "an imperialistic point of view" with regard to each other and pretended to be masters over their "brethren" on account of "our history" or of "our advanced culture". Despite

\footnotetext{
${ }^{7}$ Bogmeji $=$ those who swear "bog me', i.e. Kajkavian speakers.
} 
the rhetoric of unification, calling out "Unite!" or "The wall has to fall!", in reality Southern Slavs looked down upon their more eastern and/or southern "brethren" (Ilešič 1910: 19).

Regardless of such viewpoints, in 1918 the great majority of Slovenes enthusiastically saluted the nation state of Southern Slavs. The enthusiasm, though, largely faded away during the first years of its existence, particularly after the constituent assembly adopted the "Greater Serbian" Vidovdan Constitution. Then, many Slovenes changed their opinion about the new state. According to Slovenec, they realised that under the notion of unification, liberation, and so on, "our brothers imagine simply the most shameless sucking of enslaved Slovenes, Croats, and other prečani"," that due to the Belgrade čaršija politics of "unscrupulous squeezing and plundering" they were losing "step by step even what they had achieved within Austria, and we went Balkan all along the line". Slovenec maintained that it was out of the question that in the twentieth century "an immoral gang of plunderers lastingly oppresses two advanced nations who had scooped their culture from the West" (Anon. 1923b: 1).

Within this context, a new mythological creature was born. The Slovene People's Party instigated new propaganda by claiming that the Serbian cow had "its udder in Belgrade and its mouth in Slovenia" (Anon. 1923a: 2). Although a mythological creature, it was a valuable instrument for soliciting the votes of Slovene peasants. It remained alive and kicking, and gave birth to many other mythological creatures in various parts of the common state, and even survived the death of Yugoslavia.

Such rhetoric based upon the mythology of the major cultural differences and nostalgia for the good old days, though, was not helpful for bettering knowledge of each other. Thus, instead of building bridges between themselves, they were rather constructing ever higher walls of exclusivity that separated the "three brothers". The higher the walls of exclusivity, the more they were moving away from each other. It was just a question of time before the "cultural differences" in Yugoslavia would prove just too great to be accommodated in a single state.

${ }^{8}$ Literarily: people from the other side. The term is used to denote the Southern Slavs from the other side of the borders of the Kingdom of Serbia. 


\section{REFERENCES AND SOURCES}

A Diplomatist. 1915. Nationalism and War in the Near East. Oxford: Claredon Press.

Anonymous. 1852. "Pogled v Bosno". Novice kmetijskih, obertnijskih in narodskih rečí, 5 May, 143.

Anonymous. 1853. "Ozir po svetu”. Novice kmetijskih, obertnijskih in narodskih rečí, 16 November, 366.

Anonymous. 1853. "Narodi po Turčíi". Novice kmetijskih, obertnijskih in narodskih rečí, 26 November, 378-379.

Anonymous. 1854. “Černo morje”. Novice kmetijskih, obertnijskih in narodskih rečí, 14 January, 16.

Anonymous. 1866. "Iz Belega grada”. Novice gospodarske, obrtniške in narodne, 21 March, 96-97.

Anonymous. 1868. “Turčija”. KRN, Novice gospodarske, obrtniške in narodne, 18 March, 92.

Anonymous. 1870a. "Iz Ljubljane”. Slovenski Narod, 8 October, 2-3.

Anonymous. 1870b. "K slovanskemu vprašanju”. Slovenski Narod, 18 October, 1.

Anonymous. 1877a. "Iz Rusko-Turškega bojišča”. Novice gospodarske, obrtniške in narodne, 18 July, 234.

Anonymous. 1877b. “Zakaj Rusom želimo zmage?” Slovenec, 14 August, 1-2.

Anonymous. 1877c. "Lažipreroki”. Slovenec, 4 September, 1.

Anonymous. 1878a. "Ali nam bode rusko-turška vojska kaj koristila?” Slovenec, 31 January, $1-2$.

Anonymous. 1878b. “Iz avstrijske delegacije”. Soča, 18 March, 1-2.

Anonymous. 1878c. "Iz Banjaluke”. Slovenski Narod, 28 August, 1.

Anonymous. 1908a. "Rodoljubnosti čast". Slovenski Narod, 1 April, 1-2.

Anonymous. 1908b. “Tridesetletnica okupacije Bosne in Hercegovine”. Edinost, 29 July, 1-2.

Anonymous. 1908. "Bolgari, Srbi, Hrvatje in Slovenci". Edinost, 8 October, 2.

Anonymous. 1913. "Nepoboljšljivi”. Slovenski Narod, 14 February, 1.

Anonymous. 1918. "Ljubljana manifestira za Jugoslavijo". Slovenec, 26 March, 1-3.

Anonymous. 1919a. "Za naše meje”. Slovenec, 29 January, 2

Anonimous. 1919b. “Čemu se nadja švaba”. Slovenec, 9 March, 5.

Anonymous. 1919c. "Novinski pregled”. Slovenski Narod, 27 March, 2-3.

Anonymous. 1920. "Reško vprašanje in JDS". Slovenec, 10 April, 1.

Anonymous. 1923a. "Kdo je kriv?" Slovenski Gospodar, 25 October, 2.

Anonymous. 1923b. "Naš in njihov zamisel”. Slovenec, 17 November, 1.

Anonymous. 1924. "Kaj je z velesrbstvom?” Slovenski Narod, 30 April, 1.

Anonymous. 1927a. “Na cesto!" Slovenec, 2 March, 1.

Anonymous. 1927b. "Trgovinske pogodbe pred Narodno skupščino”. Slovenski Narod, 25 November, 1.

Anonymous. 1929. "Od Ilirije do Jugoslavije”. Slovenec, 13 October, 1.

Aristides. 1934. “Ali smo se zedinili? Ujedinili? Uedinili?” Slovenec, 23 December, 4.

Berend, Ivan T. 2003. History Derailed. Central and Eastern Europe in the Long Nineteenth Century. Berkeley: University of California Press. 
Cankar, Ivan. 1959. "Slovenci in Jugoslovani”. Izbrana dela, 10. Ljubljana: Cankarjeva založba, 392-393.

Chakrabarty, Dipesh. 1992. "Provincializing Europe. Postcoloniality and the Critique of History". Cultural Studies 3: 337-357. [http://dx.doi.org/10.1080/09502389200490221]

- č -. 1877. “Glejmo nazaj, da vidimo naprej!” Novice gospodarske, obrtniške in narodne, 7 and 14 February, 45, 53-54.

D. P. 1935. "Avstrija in njen položaj v Evropi". Ljubljanski Zvon 11: 41-47.

Dolenec, J. 1921. "H. Wendel o Jugoslaviji”. Čas, 365-371.

Hadžić, Stevan. 1929. “Izjave vojnega ministra 'Slovencu”'. Slovenec, 15 October, 1.

Hobsbawm, Eric. 1975. The Age of Capital: 1848-1875. New York: Vintage Books.

Ilešič, Fran. 1910. "Županić Niko dr: Izveštaj o antropološkom i paleontološkom radu u Narodnom muzeju i ekskurziji u Beloj Kranjskoj". Slovan, 352-353.

Ilešič, Fran. 1913. "Dr. Niko Županić: Altserbien und die albanesische Frage. Wien, 1912". Slovan, 125-126.

Izv. Dop. 1877. "Sokolski izlet”. Slovenski Narod, 17 May, 3.

Izv. dop. 1878. "Na Gorenjskem”. Slovenski Narod, 15 February, 2.

Jagić, Vatroslav. 1895. "Ein Kapitel zur Geschichte der südslavischen Sprachen”. Archiv für slavische Philologie 17: 47-87.

Jezernik, Božidar. 2004. Wild Europe. The Balkans in the Gaze of Western Travellers. London: Saqi Books.

Jezernik, Božidar. 2006. "Power of Remembrance, Supremacy of Oblivion. History of the 'National Monuments' in Ljubljana". Peter J. M. Nas and Annemarie Samuels, eds. Hypercity. The Symbolic Side of Urbanism. London: Kegan Paul, 85-112.

Jezernik, Božidar. 2010. “Valentin Vodnik, 'the First Slovenian Poet.' The Politics of Interpretations". Slovene Studies 1-2: 19-42.

Korošec, Anton, Ante Pavelić and Svetozar Pribičević. 1918. "Za popolno svobodo in ujedinjenje SHS". Slovenec, 21 October, 1.

Kotnik, France. 1927/28. “Etnolog”. Čas, 341-342.

Kveder-Jelovšek, Zofka. 1907. "Žene Mohamedanke v Bosni in Hercegovini". Slovenski Narod, 10 August, $1-3$.

Leskovec, Janko. 1918. "Srbi in mi”. Jugoslavija, 18 December, 1-2.

M. M. R. 1920. "K vprašanju o enotnem književnem jeziku”. Slovenski Narod, 4 July, 1.

Melik, Vasilij. 1997. "Slovenci o Germanih, Slovanih in Romanih pred 120 leti". Zgodovinski časopis 1: 17-20.

Nadel-Klein, Jane. 1996. “Occidentalism as a Cottage Industry. Representing the Autochthonous 'Other' in British and Irish Rural Studies". James G. Carrier, ed. Occidentalism. Images of the West. Oxford: Clarendon Press, 109-134.

Nikočević, Lidija. 2008. Iz "etnološkog mraka". Austrijski etnografski tekstovi o Istri s kraja 19. i poćetka 20. stoljeća. Pula: Zavičajna naklada "Žakan Juri”.

Podgoriški. 1862. "Turško". Novice gospodarske, obrtniške in narodne, 24 September, 327-328.

Potočnik, Franjo. 1878. “Bolgarija in Bolgari”. Slovenski Narod, 21 February, 1-3.

Pripravljalni odbor. 1913. Slovensko-hrvatski katoliški shod v Ljubljani 1913. Ljubljana: Katoliška Bukvarna.

Res, Alojzij. 1919. “Naša nova kulturna orijentacija”. Edinost, 19 October, 2. 
Rihtman-Auguštin, Dunja. 2000. Ulice moga grada. Antropologija domaćeg terena. Beograd: Biblioteka XX vek.

Rus, Jože. 1929. “Napoleon reče: 'Ilirija vstan'!” Jutro, 13 October, 7-8.

Rybář, Otokar. 1913. "Vpliv balkanske vojne na naše gospodarske in politične razmere. Govor državnega poslanca g. dr. Otokarja Rybářa na javnem shodu političnega društva 'Edinosti' dne 12. januarja l. 1913.". Edinost, 15 January, 3-4.

Seidl, Ferdinand. 1919. "Kod naj se potegne pravična državna meja med Jugoslavijo in Italijo?" Slovenski Narod, 1 February, 2.

Simonič, Peter. 2010. "Valvasor's Hereditary Enemy". In Imagining "the Turk". Božidar Jezernik, ed. Cambridge Scholars Publishing, 67-83.

Skene, James Henry. 1853. The Frontier Lands of the Christian and the Turk. London: Richard Bentley.

Slovenski oficir. 1878. "Kratek pregled rusko-turške vojne v Evropi in njen značaj”. Slovenski Narod, 12 March, 1-2.

U. F. 1920. “K vprašanju o enotnem književnem jeziku”. Slovenski Narod, 13 May, 1.

Ušeničnik, Aleš. 1914. "Jugoslovansko vprašanje”. Slovenec, June 24, 1.

Vošnjak, Bogumil. 1916. Political and Social Conditions in Slovene Lands (Carniola, Carinthia, Illyrian Littoral and Styria). London: The Near East.

Vošnjak, Bogumil. 1919. “Domovini”. Slovenec, 7 January, 1.

Vošnjak, Josip. 1912. "Vstaja balkanskih Slovanov 1875-1878 in Slovenci”. Veda, 56-59.

Weber, Eugen. 1977. Peasants into Frenchmen. The Modernization of Rural France, 1870-1914. London: Chatto and Windus.

Zupanič, Niko. 1916. Slovenija vstani! Cleveland, Ohio: Tiskarna "Clevelandske Amerike”.

Županić. Niko. 1907. “Ilirija”. Ljubljanski Zvon, 486-492, 554-557, 615-620.

\section{SLOVENCI, BALKAN I JUGOSLAVENSKA IDEJA, ILI KRATKA PRIČA O DUGAČKOJ KRAVI}

U jednom od svojih radova Dunja Rihtman-Auguštin (2000: 211-236) raspravlja o izboru riječi u suvremenom hrvatskom političkom govoru kojim su političari krajem dvadesetog stoljeća mobilizirali svoje birače da izraze stavove o tome što Nam je dobro i prihvatljivo, a što Nam je neprihvatljivo. U izvrsnom članku, punom duhovitih uvida, Rihtman-Auguštin pokazuje da koncept Balkana pripada povijesti u istoj mjeri kao i imaginaciji. Premda je Balkan uvijek istočno od Nas, kaže Rihtman-Auguštin, balkanski je mentalitet ovdje, s Nama, a ne negdje drugdje. Njezin me je rad potaknuo da analiziram povijest i predodžbu termina Balkan u slovenskome u drugoj polovici devetnaestog i ranom dvadesetom stoljeću, odnosno u vrijeme kad se razvijala slovenska nacionalna svijest.

Ključne riječi: modernost, Osmansko Carstvo, slovenski nacionalizam, Balkan, Jugoslavija 